1943b. Ueber die Entwickl, pseudogamer Potentillen. Arch. Julius Klaus-Stiftung 18: 687-691.

—. 1943c. Untersuch. ueber die Fortpfl. und Bastardbildung apomiktischer Potentillen. Ber. Schweiz. Bot. Ges. 53: 1-83.

—_. 1945a. Ueber die Fortpfl. einiger Bastarde von pseudogamen Potentillen. Arch. Julius Klaus-Stiftung, erganzungsband $\mathrm{zu}$ band 20:300-314.

1945b. Zur Embryologie amphimiktischer Potentillen. Ber. Schweiz. Bot. Ges. 55: 19-22.

1946. Ueber kreuzungeversuche mit pseudogamen Potentillen. Arch. Julius Klaus-Stiftung 21: 469-472.

1947. Untersuch. ueber die Genetik der Aposporie bei pseudogamen Potentillen. Experientia 3: 204.

Satina, Sophie, And A. F. Blakeslee. 1935. Cytological effects of a gene in Datura which causes dyad formation in sporogenesis. Bot. Gaz. 96: 521-532.
SAx, K. 1931. The origin and relationships of the Pomoideae. Jour. Arnold Arboretum 12: 3-22.

Stebbins, G. L. 1932a. Cytology of Antennaria. I. Normal species. Bot. Gaz. 94: 134-151.

-. 1932b. Cytology of Antennaria. II. Parthenogenetic species. Bot. Gaz. 94: 322-344.

_— And J. A. Jenkins. 1939. Aposporic development in the North American species of Crepis. Genetica 21: 191-224.

. 1941. Apomixis in the angiosperms. Bot. Rev. 7: 507-542.

Stenar, H. 1932. Parthenogenesis in der Gattung Calamagrostis. Arkiv. Bot. 25: 1-8.

Tinney, F. W. 1940. Cytology of parthenogenesis in Poa pratensis. Jour. Agric. Res. $60: 351-360$.

Zweifel, R. 1939. Cytologisch.embryologische Untersuch. an Balanophora abbreviata Blume und $B$. indica. Diss. Zurich.

\title{
FOSSIL PINE POLLEN SIZE-FREQUENCIES IN HEART LAKE SEDIMENTS, OAKLAND COUNTY, MICHIGAN ${ }^{1}$
}

\author{
Stanley A. Cain, Louise G. Cain, and George Thomson
}

Palynological studies of Sodon Lake sediments (Cain, 1948; Cain and Cain, 1948; Cain and Slater, 1948) have been extended to include a similar series of investigations of Heart Lake sediments. Heart Lake also lies in the Defiance Moraine (Leverett and Taylor, 1915) about 16 miles northeast of Sodon Lake. It is in the highest part of the moraine at an elevation of about 1,000 feet, and, like Sodon Lake, is probably a kettle pond in which sedimentation commenced some time after the withdrawal of the ice sheet from the vicinity.

The general pollen analysis, which has been worked out by Bunt (1950), begins with a truncated record of the Pre-boreal spruce-fir time at $21.5 \mathrm{ft}$. depth in compact marl. This is followed shortly by a prominent pine development which marks the Boreal period. Pine already composes about 35 per cent of the pollen during the waning spruce-fir period at $21.5-21.0 \mathrm{ft}$. depth. It reaches a culmination of 63.4 per cent of the pollen at the $20.5 \mathrm{ft}$. level, after which there is maintained an average pine composition in successive spectra of about 5 per cent. During the waning of the pine period there is a rise in combined mixed mesophytes (beech, maple, hemlock, basswood, carpinus), marking the Atlantic period and culminating at the close of the pine period. The Atlantic period merges gradually with the ascendancy of oakhickory, which is predominant through the upper four-fifths of the profile. A Sub-Boreal period is

1 Received for publication March 20, 1951.

This investigation was carried out in the laboratory of The Cranbrook Institute of Science, Bloomfield Hills, Michigan. The authors wish to express their appreciation to Dr. Robert H. Hatt, Director of the Institute. Mr. Thomson is associated with Ethyl Corporation, Detroit. not recognizable and there is only a suggestion of a final revertence characteristic of the Sub-Atlantic period.

In the Sodon Lake studies, Cain and Cain (1948), by means of size-frequency data on both modern and fossil pine pollen, endeavored to reconstruct the outlines of pine history in southeastern Michigan. The present study is a similar effort, the results of which rather closely parallel those previously reported, lending support to what, by its nature, must be largely circumstantial evidence.

In general, the Heart Lake sediments yielded poor pollen material, both in abundance and in quality, but the lower levels provided much better pollen preservation and for some spectra an abundance of good pollen. We are presenting the measurements of fossil pine pollen ${ }^{2}$ in two groups in table 1 and fig. 1. This division of the data is logical for two reasons: The first group, based on 904 measurable grains from seven levels (18.5-21.5 ft.), covers the Boreal pine period; it also includes the spectra in which the size-frequency histograms for fossil pine pollen grains are bimodal. In the series of levels above this (13.0-18.0 ft.) that include the Atlantic period, the size-frequency curves for fossil pine pollen become trimodal.

The modes in the size-frequency data suggest that different species of pine, differing significantly in size, contributed to the pollen rain of the Heart Lake sedimentary basin and, furthermore, that two species were present in the region during the spruce-

2 All measurements were made from sound, inflated grains at the point of greatest grain diameter. The measurements were made between points of outer wing insertions, excluding the exine which is variable in thickness, at a magnifcation of $860 \times$. 


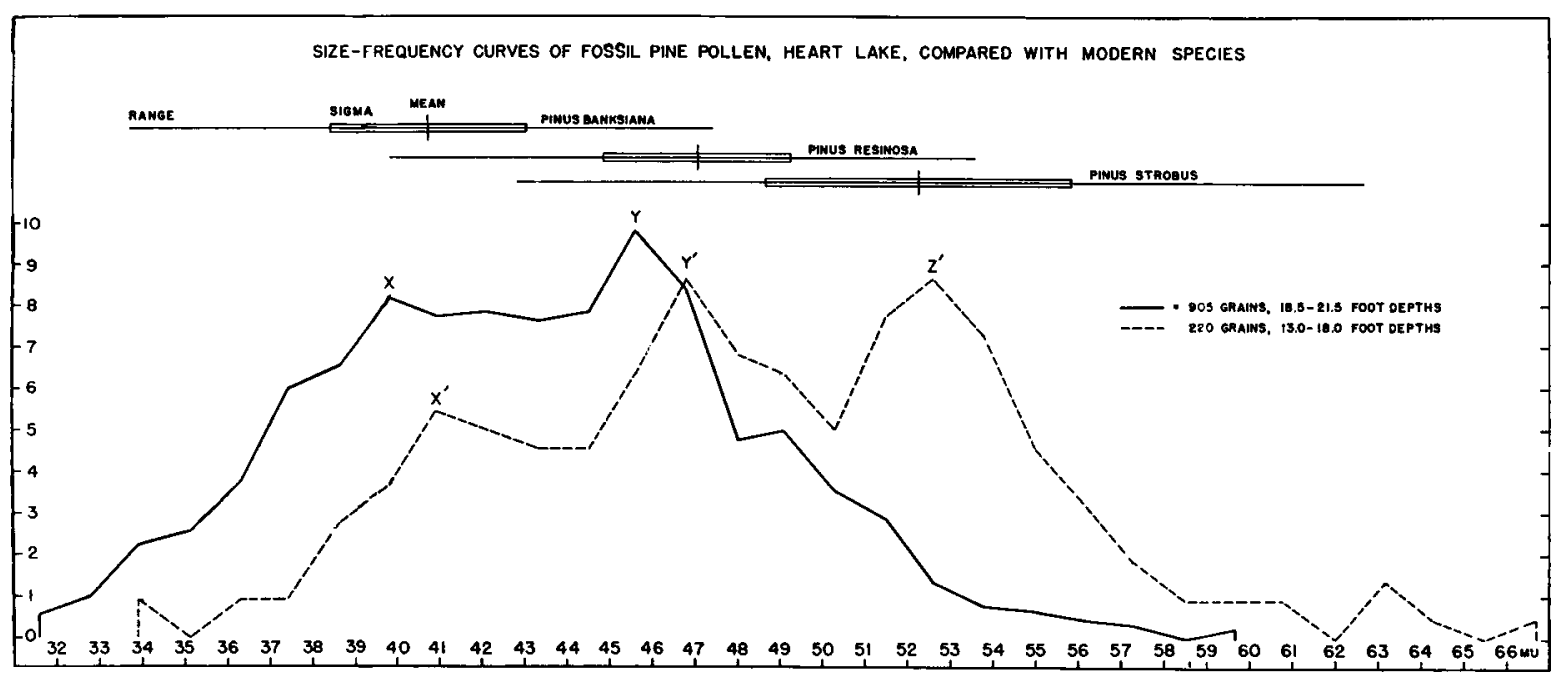

Fig. 1. Size-frequency curves of fossil pine pollen, Heart Lake, compared with modern species.

fir period and the pine period, and that a third species became of importance in the area during hardwood dominance after the pine period was over, although it may have been present in small amounts at an earlier time. There are no reasons in the modern geography of pine species of eastern North America to look farther afield for possible pine species present in the Heart Lake region at earlier times than to the three pine species now native in Michigan. These three species are the jack pin? (Pinus Banksiana), the red pine ( $P$. resinosa), and the white pine $(P$. Strobus).

The pollen grains of these species do not have known diagnostic characters other than size so that the circumstantial evidence of pine history must be based on comparisons between size-frequency characteristics of fossil and modern pollen grains. Table 1 and fig. 1 show that the modal size for smallest grains is $39.8 \mu$ for the lower levels and $40.9 \mu$ for the second group of measurements. This is designated as mode $\mathrm{X}$ and is referred to Pinus Banksiana, the eastern American pine with smallest pollen grains (Cain, 1940, 1944; Cain and Cain, 1948). The second mode (Y) is at $45.6 \mu$ for the first group and $46.8 \mu$ for the second group of levels. This is referred to $P$. resinosa. The third mode $(Z)$ is not present in the early series of spectra but is well marked in the data for the levels above 18.5 ft. It falls at $52.6 \mu$ and is referred to P. Strobus.

If the principle of "identification" of fossil grains with grains of modern species on a basis of size characteristics is valid, and if the supplementary ecological reasoning earlier presented by Cain and Cain (1948) is also valid, we may make the following conclusions with respect to pine history in southeastern Michigan.

During the waning spruce-fir period, pine was already abundant in the region of Heart Lake. Species of all these conifer genera are heavy pollen producers and are probably over-represented in spectra in relation to many broadleaf, deciduous genera. But among themselves, we have no basis in data for doing otherwise than accepting winged conifer pollen percentages at their face value. There is a suggestion here, then, that $P$. Banksiana was comparatively more abundant during the pine period (modal value of 8.2 per cent for the grains from $18.5-21.5 \mathrm{ft}$.) than it was later (modal value of 5.4 per cent). During both periods putative $P$. resinosa was somewhat more abundant than $P$. Banksiana (modal values of 9.8 and 8.6 per cent, respectively). Pinus Strobus appears to have entered the region much later than the other species, only a suggestion of its presence being found in the few grains of large size in the lower levels of the sediments. Soon after the pine period, mode Z ( $P$. Strobus) made its appearance and, in the collective data for the second period, it enters the record on a par with $P$. resinosa. The pine belt of the Lake Forest (Nichols, 1935) today lies north of the Heart Lake area, but $P$. Strobus is still native in the region of this study, occurring as scattered individuals, sometimes a few trees per acre in old forests on sufficiently mesic sites. A few trees, in fact, occur in the immediate vicinity of Heart Lake.

In grain size, in mesophily, and in the geographic series of species areas from north to south these three species of pines present a consistent sequence: Banksiana-resinosa-Strobus. It is thought that the above account of pine history in southeastern Michigan is essentially true, and that the size-frequency data and those from the contemporary ecology and distribution of the species support one another.

In the Sodon Lake studies (Cain and Cain, 1948) a composite size-frequency curve for fossil pine pollen from the lowest levels was bimodal (modes X and $\mathrm{Y}$, referred to $P$. Banksiana and $P$. resinosa). At higher levels a third mode $(\mathrm{Z})$, referred to $P$. 
TABLE 1. Size-frequency distribution of fossil pine pollen grains, Heart Lake. ${ }^{a}$

\begin{tabular}{|c|c|c|c|c|c|c|c|}
\hline lines & rons & $\begin{array}{l}\text { Grain } \\
\text { at the }\end{array}$ & $\begin{array}{l}\text { nents } \\
\text { level }\end{array}$ & $\begin{array}{l}\text { Grai } \\
\text { betw }\end{array}$ & iments & $\begin{array}{c}\text { Grains } \\
\text { between }\end{array}$ & $\begin{array}{l}\text { in sediments } \\
13.0-18.0 \mathrm{ft} \text {. }\end{array}$ \\
\hline 26 & 30.4 & 1 & 0.1 & - & - & - & - \\
\hline 27 & 31.6 & 5 & 0.6 & 5 & 0.5 & - & - \\
\hline 28 & 32.8 & 5 & 0.6 & 9 & 1.0 & - & - \\
\hline 29 & 33.9 & 11 & 1.4 & 20 & 2.2 & 2 & 0.9 \\
\hline 30 & 35.1 & 15 & 1.9 & 23 & 2.5 & - & - \\
\hline 31 & 36.3 & 27 & 3.4 & 34 & 3.7 & 2 & 0.9 \\
\hline 32 & 37.4 & 39 & 4.9 & 54 & 6.0 & 2 & 0.9 \\
\hline 33 & 38.6 & 58 & 7.2 & 59 & 6.5 & 6 & 2.7 \\
\hline 34 & 39.8 & 69 & 8.6 & 74 & 8.2 & 8 & 3.6 \\
\hline 35 & 40.9 & 65 & 8.1 & 70 & 7.7 & 12 & 5.4 \\
\hline 36 & 42.1 & 61 & 7.6 & 71 & 7.8 & 11 & 5.0 \\
\hline 37 & 43.3 & 59 & 7.4 & 69 & 7.6 & 10 & 4.5 \\
\hline 38 & 44.5 & 78 & 9.7 & 71 & 7.8 & 10 & 4.5 \\
\hline 39 & 45.6 & 95 & 11.9 & 89 & 9.8 & 14 & 6.4 \\
\hline 40 & 46.8 & 65 & 8.1 & 76 & 8.4 & 19 & 8.6 \\
\hline 41 & 48.0 & 40 & 5.0 & 43 & 4.7 & 15 & 6.8 \\
\hline 42 & 49.1 & 40 & 5.0 & 45 & 5.0 & 14 & 6.4 \\
\hline 43 & 50.3 & 30 & 3.7 & 32 & 3.5 & 11 & 5.0 \\
\hline 44 & 51.5 & 17 & 2.1 & 26 & 2.9 & 17 & 7.7 \\
\hline 45 & 52.6 & 8 & 1.0 & 12 & 1.3 & 19 & 8.6 \\
\hline 46 & 53.8 & 4 & 0.5 & 7 & 0.8 & 16 & 7.3 \\
\hline 47 & 55.0 & 5 & 0.6 & 6 & 0.7 & 10 & 4.5 \\
\hline 48 & 56.2 & 3 & 0.4 & 4 & 0.4 & 7 & 3.2 \\
\hline 49 & 57.3 & -- & - & 3 & 0.3 & 4 & 1.8 \\
\hline 50 & 58.5 & - & - & - & - & 2 & 0.9 \\
\hline 51 & 59.7 & - & - & 2 & 0.2 & 2 & 0.9 \\
\hline 52 & 60.8 & - & - & - & - & 2 & 0.9 \\
\hline 53 & 62.0 & - & - & - & - & - & - \\
\hline 54 & 63.2 & - & - & - & - & 3 & 1.4 \\
\hline 55 & 64.3 & -- & - & - & - & 1 & 0.4 \\
\hline 56 & 65.5 & - & - & - & - & - & - \\
\hline 57 & 66.7 & - & - & - & - & 1 & 0.4 \\
\hline Number of & & 800 & & 904 & & 220 & \\
\hline
\end{tabular}

${ }^{\mathrm{a}} 1$ line $=1.17 \mu$.

b The large additional series of grains measured at this one level shows no significant difference from the series for the lower levels generally.

Strobus, was present. These results correspond with those reported here for Heart Lake. The modal values in the two cases compare as follows: Mode X-Sodon Lake, 38.6-40.2 $\mu$, Heart Lake,

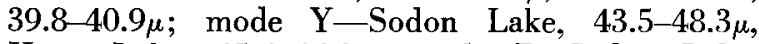
Heart Lake, 45.6-46.8 $\mu$; mode Z-Sodon Lake, $54.1 \mu$, Heart Lake, $52.6 \mu$. These modal values are of the same order and are also well within the range of mean values for different collections of pollen of $P$. resinosa and $P$. Strobus, but they are at the small end of the range of mean values for P. Banksiana (Cain, 1940; Cain and Cain, 1948).

In the Sodon Lake study a composite curve for intermediate levels showed mode $\mathrm{X}$ in consistent position. The second mode, however, was strongly developed and situated between the size positions indicated for $Y$ and $Z$. This was interpreted as a result of the combination (overlay) of size-frequency curves of $\mathrm{Y}$ and $\mathrm{Z}$.

The problem of composite curves where the data of two or more statistical populations are mixed has likewise been studied by the authors. This problem is approached in two ways. In the first case, data from size-frequency studies of various selected collections of pollen of $P$. Banksiana, resin$o s a$ and Strobus are combined to form composite curves which are compared with those of fossil pollen. In the second case, curve-fitting to the data on fossils is attempted on a basis of assumed means, standard deviation, and ratios of statistical populations of the species concerned. ${ }^{3}$

In table 2 are data on the size-frequency characteristics of one collection each of $P$. Banksiana and P. Strobus (Collection No. 178 and 152), and three collections of $P$. resinosa (Collection No. 140, $162,136)$. Each of these collections is represented by 150 measured grains. In the right-hand half of

${ }^{3}$ This work is the contribution to this paper of Mr. George Thomson. 
table 2 the data are expressed as percentages in three sets combining the results for $P$. Banksiana and $P$. Strobus successively with each of the collections for $P$. resinosa.

In the first set the data for collections No. 178, 140 and 152 are combined. These collections were selected from among the thirty-two collections available (Cain and Cain, 1948) because their means were close to the modal values $X, Y$ and $Z$ for fossil material, and because their frequency distributions approached normal. It is to be seen in fig. 2 that this combination of data for the three species produced a bimodal rather than a trimodal curve, because of the extent of overlap of the histograms for $P$. Banksiana and $P$. resinosa. Should such a combined curve be the only type obtained for fossil material, the contribution to the fossil material of grains of three species would not be obvious. It is for this reason that measurements for each level studied should be kept separate and only combined later as the individual results warrant.

Since the combination curve of the first set was not similar to that found in the fossil material, a second set was prepared using a different collection of $P$. resinosa (Collection No. 162), the mean of which was $47.04 \pm 2.23 \mu(1.67 \mu$ larger than 140). This combination produced a trimodal curve, fig. 3. A third set was prepared next, using collection No. 136 of $P$. resinosa, with a mean value of $49.21 \pm 2.34 \mu$, which is $2.17 \mu$ larger than that of the preceding collection (No. 162). This combination again produced a trimodal curve, fig. 4 . Neither of these curves bears a really close resem- blance to the trimodal curve for fossil pine pollen from Heart Lake, although the latter is the closer. It is not to be expected that this method would produce closely comparable curves for the following reasons: in the experimental curves each species contributes equally, whereas in the fossil material the ratios of the three species are unknown but likely different. The second difference lies in the restriction of the data in the experimental curves to one collection for each species in which the standard deviation and the range are both smaller than would be expected for the heterogeneous collection of fossil grains in the sediments which have been derived from numerous trees of the area over many seasons.

In a recent article, Court (1949) has pointed out that a simple procedure may be employed for separating a frequency distribution into a sum of two normal components. The method is based on the assumption of the two means of the component distributions which are adjusted by trial until the sum of the components agrees with the observed distribution. The required data are the mean, standard deviation (or variance) and third moment (or skewness) of the data; the procedure gives for any pair of assumed means the component proportions and variances. This procedure looked promising for the size-frequency distribution of the pollen grains found between 18.5 and $21.5 \mathrm{ft}$. since the plotted distribution data (fig. 1) were bimodal and could conceivably have arisen from the addition of two normal components. However, despite a considerable number of trials no pair of means was

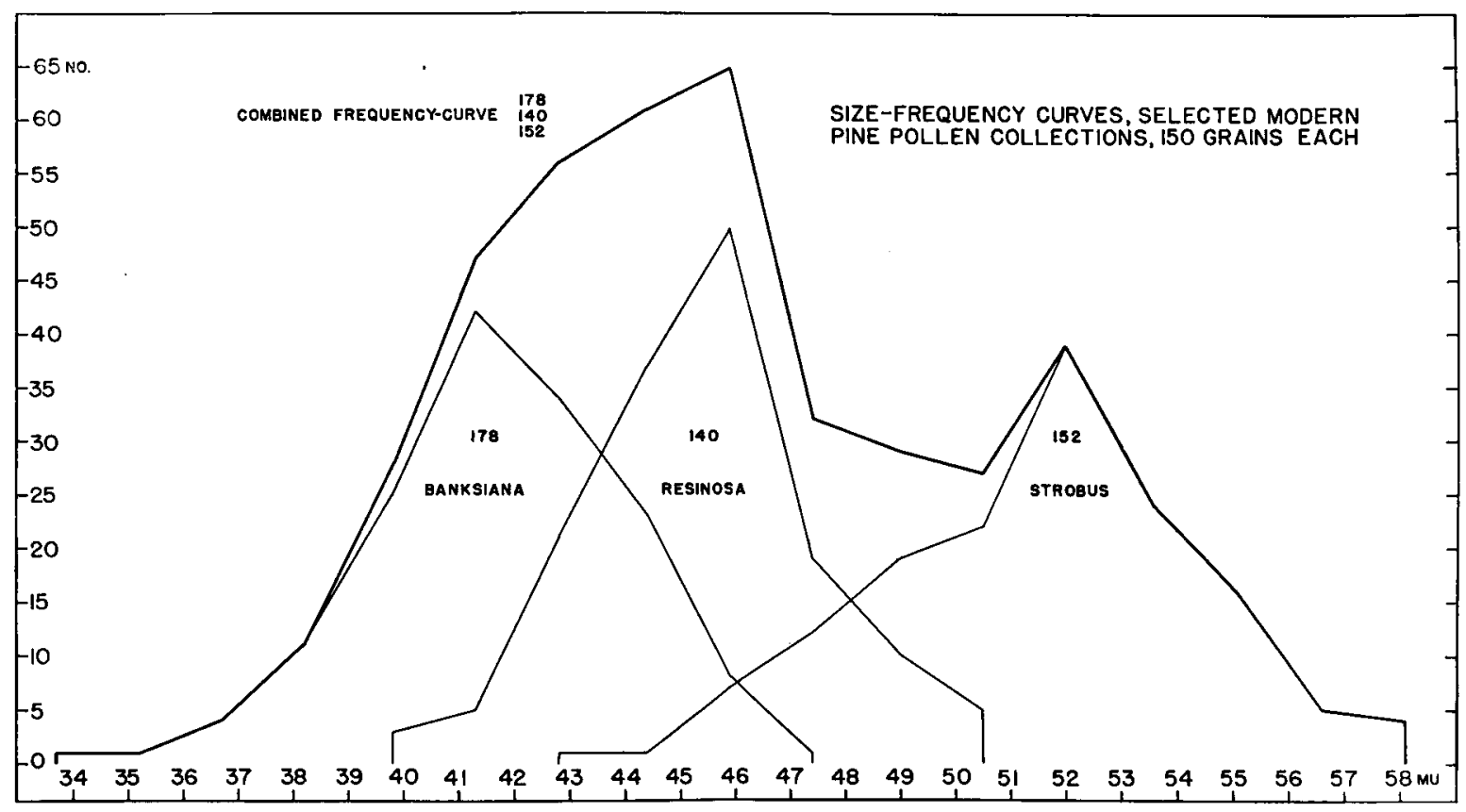

Fig. 2. Separate and combined frequency curves for measurements of pollen grains of three species of pine, collections No. 178, 140, and 152 . 
TABLE 2. Combined statistics for collections of modern pollen of selected pine species.

\begin{tabular}{|c|c|c|c|c|c|c|c|c|}
\hline $\begin{array}{l}\text { Grain size } \\
\text { in microns }\end{array}$ & $\begin{array}{c}\text { P. Banksiana } \\
\text { Coll. } 178\end{array}$ & \multicolumn{3}{|c|}{ umber of pollen grains by size classes } & $\begin{array}{l} \\
\text { P. Strobus } \\
\text { Coll. } 152\end{array}$ & \multicolumn{3}{|c|}{$\begin{array}{l}\text { Combined percentages, collections of } \\
\text { the } 3 \text { species, with different collections } \\
\text { of } P \text {. resinosa. }\end{array}$} \\
\hline 33.7 & 1 & - & - & - & - & 0.22 & 0.22 & 0.22 \\
\hline 35.2 & 1 & - & - & - & - & 0.22 & 0.22 & 0.22 \\
\hline 36.7 & 4 & - & - & - & - & 0.89 & 0.89 & 0.89 \\
\hline 38.2 & 11 & - & - & - & - & 2.44 & 2.44 & 2.44 \\
\hline 39.8 & 25 & 3 & 1 & - & - & 6.22 & 5.78 & 5.55 \\
\hline 41.3 & 42 & 5 & - & - & - & 10.44 & 9.33 & 9.33 \\
\hline 42.8 & 34 & 21 & 10 & 1 & 1 & 12.44 & 10.00 & 8.00 \\
\hline 44.4 & 23 & 37 & 25 & 4 & 1 & 13.55 & 10.89 & 6.22 \\
\hline 45.9 & 8 & 50 & 27 & 15 & 7 & 14.44 & 9.33 & 6.67 \\
\hline 47.4 & 1 & 19 & 38 & 29 & 12 & 7.11 & 11.33 & 9.33 \\
\hline 49.0 & - & 10 & 30 & 43 & 19 & 6.44 & 10.89 & 13.78 \\
\hline 50.5 & - & 5 & 14 & 28 & 22 & 6.00 & 8.00 & 11.11 \\
\hline 52.0 & - & - & 4 & 22 & 39 & 8.67 & 9.55 & 13.55 \\
\hline 53.6 & - & - & 1 & 5 & 24 & 5.33 & 5.55 & 6.44 \\
\hline 55.1 & - & - & - & 2 & 16 & 3.55 & 3.55 & 4.00 \\
\hline 56.6 & - & - & - & 1 & 5 & 1.11 & 1.11 & 1.33 \\
\hline 58.1 & - & - & - & - & 4 & 0.89 & 0.89 & 0.89 \\
\hline Number & 150 & 150 & 150 & 150 & 150 & 450 & 450 & 450 \\
\hline Mean & 40.70 & 45.37 & 47.04 & 49.21 & 52.25 & & & \\
\hline Sigma & \pm 2.33 & \pm 2.17 & \pm 2.23 & \pm 2.34 & \pm 3.61 & & & \\
\hline
\end{tabular}

found which would give a reasonable approximation to the observed distribution curve. The calculated total distribution curves were either essentially unimodal with a very small amount of skewness, or pronouncedly bimodal with a fairly deep trough. These effects are illustrated in fig. 5 and 6 which show the effect of changing one of the assumed means at a time. In fig. 5 one mean is taken to be $38.6 \mu$ (33 lines), and the effect of changing the other from $45.6 \mu$ (39 lines) to $48.0 \mu$ (41 lines) is shown. With $45.6 \mu$ the curve is unimodal and slightly skew with a fairly good fit to the tails. With $46.8 \mu$ the curve becomes bimodal, with the left mode a little lower; the right mode is still far below the modal value of the distribution. With $48.0 \mu$ the trough of the bimodal curve is very low, the components being essentially well separated and the modes are essentially equal. It is evident from an inspection of these curves that the mean of the left component cannot be $38.6 \mu$, and that it is doubtful whether the mean of the left component can be less than $38.6 \mu$. Fig. 6 presents a similar comparison where the right component mean is taken equal to $46.8 \mu$ (40 lines) and the other mean is varied from $37.4 \mu$ (32 lines) to $40.9 \mu$ (35 lines). The same type of variation occurs in this case, and it is evident that no reasonable fit can be made to the distribution when one component mean is taken equal to $46.8 \mu$. A few other trials with other combinations of assumed component means were no more successful in representing the distribution.

If the basic assumption, that the size-frequency data can be represented as a sum of two normal components, is true, the difficulty may lie in a chance condition leading to an unusually large number of pollen grains of size $45.6 \mu$. However, examination of size-frequency data for modern pollen suggests that the components may be skewed rather than normal distributions. In this case the method suggested by Court is invalid.

\section{SUMMARY}

At the time of the Pre-Boreal spruce and the Boreal pine periods, only two species of pine seem to have contributed to the pollen rain in the Heart Lake area. These are considered to be the smallgrained jack pine, Pinus Banksiana, and the somewhat larger red pine, $P$. resinosa. In the levels from depths of $18.5 \mathrm{ft}$. down, where sufficient pine pollen grains were available for measurement, the size-frequency distributions were consistently bimodal. With the termination of pine predominance, at the beginning of the Atlantic period, a third species of pine entered the area. Because of its size, this has been referred to $P$. Strobus, the white pine, which has pollen grains somewhat larger than red pine. Most sediments of this latter time did not yield an abundance of pollen, but the collective sizefrequency distribution for fossil pine pollen is definitely trimodal in this second phase. Jack pine seems to have diminished in importance with the passage of time, although it was at all times exceeded by red pine. The white pine after its late entry into the area seems to have become the pre- 
dominant species. An effort was made to simulate the bimodal and trimodal curves found for fossil pine pollen grains. The size frequencies of pollen grains from selected collections of the putative species (Pinus Banksiana, P. resinosa, P. Strobus) were added together to produce similar curves. Different populations for each species were variously combined to yield both bimodal and trimodal curves, but no close fit with the curves for fossil ma- terial was obtained. This crude technique, however, lends some credence to the assumption that the jack, red and white pines were involved in the vegetation of the Heart Lake area. Finally an attempt at mathematical analysis of the bimodal curve of fossil pollen was made by use of a procedure that can be employed for separating a frequency distribution into a sum of two normal components. The required data are the mean, standard

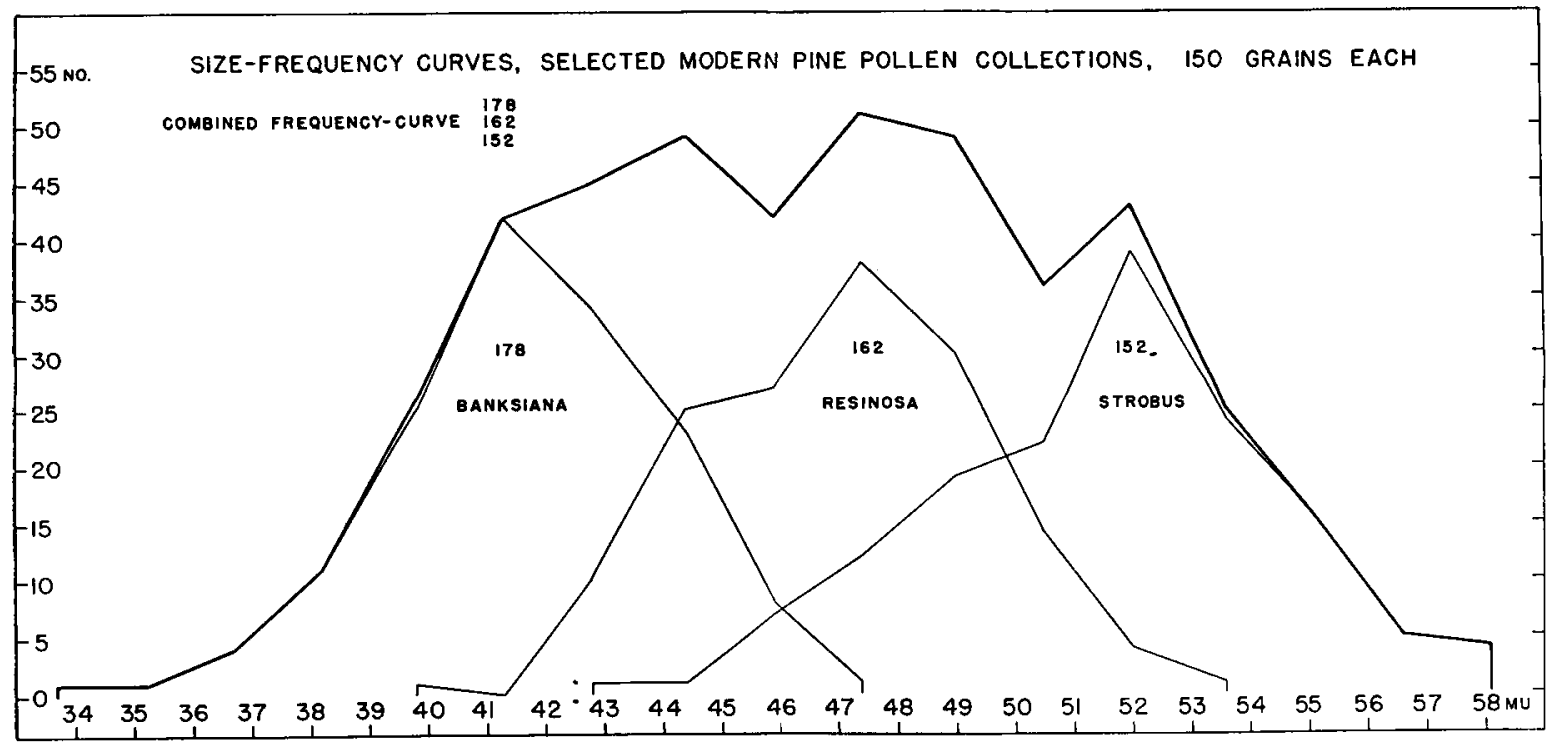

Fig. 3. Separate and combined frequency curves for measurements of pollen grains of three species of pine, collections No. 178, 162, and 152 .

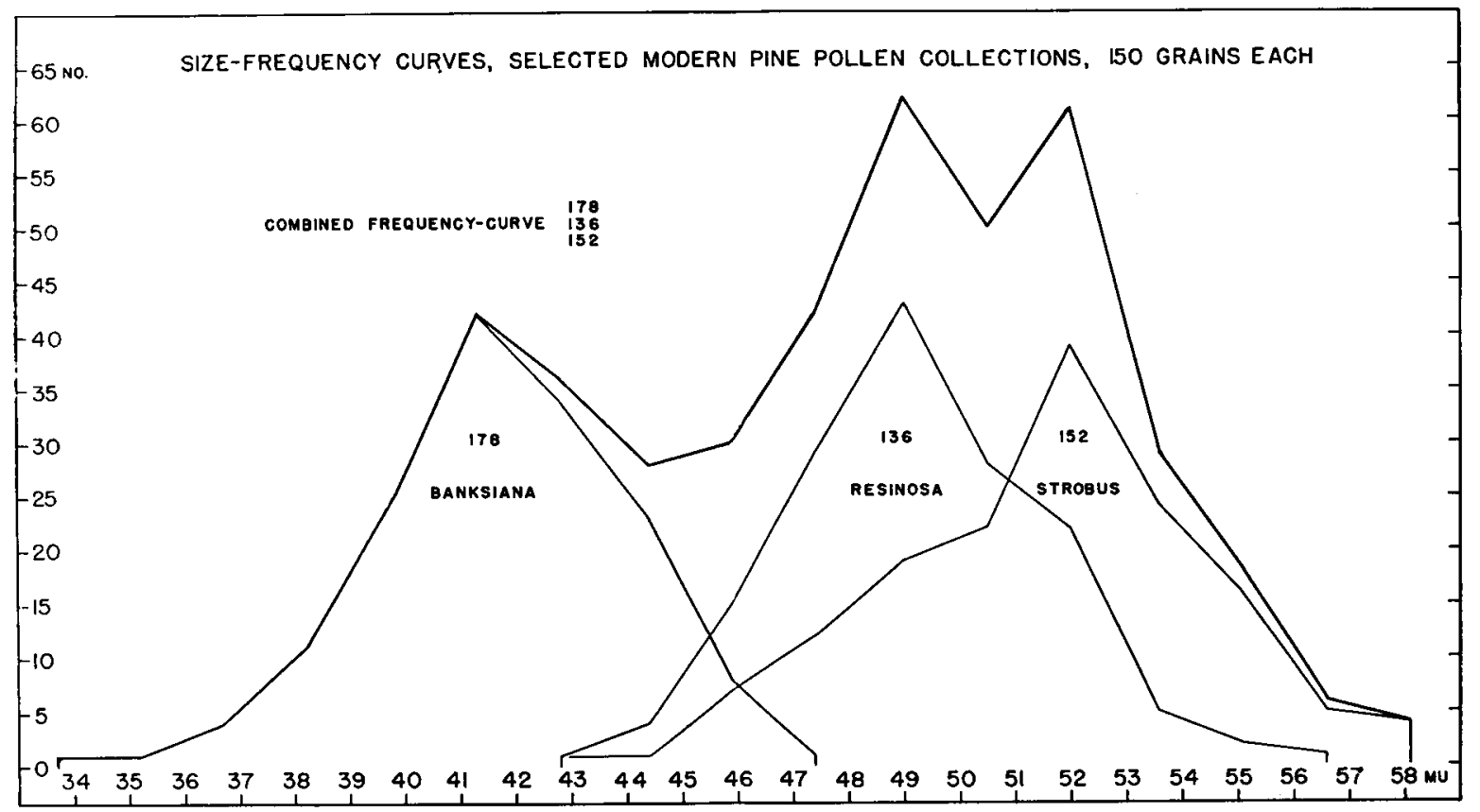

Fig. 4. Separate and combined frequency curves for measurements of pollen grains of three species of pine, collections No. 178, 136, and 152. 


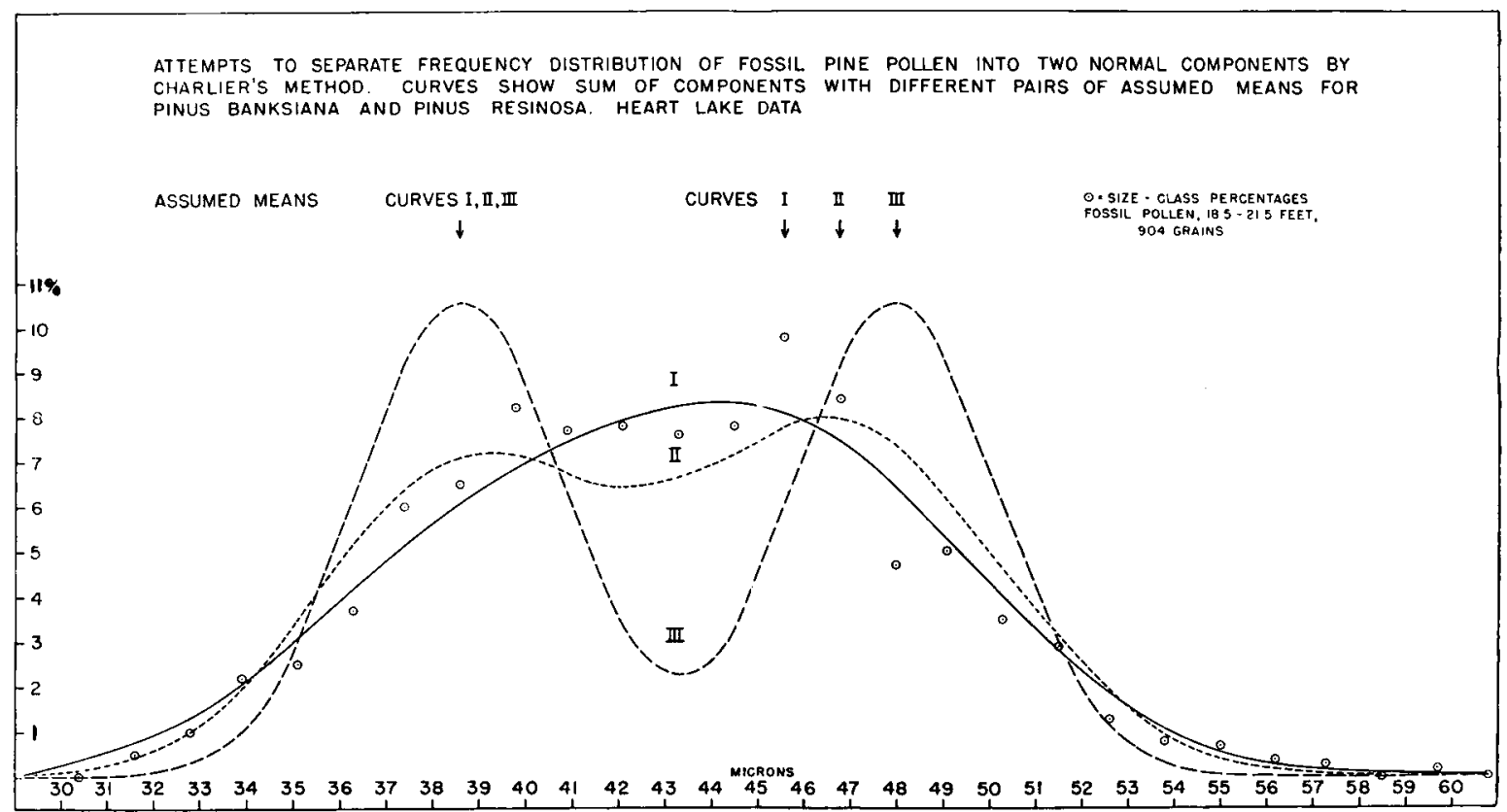

Fig. 5. Attempts to separate frequency distribution of fossil pine pollen into two normal components by Charlier's method.

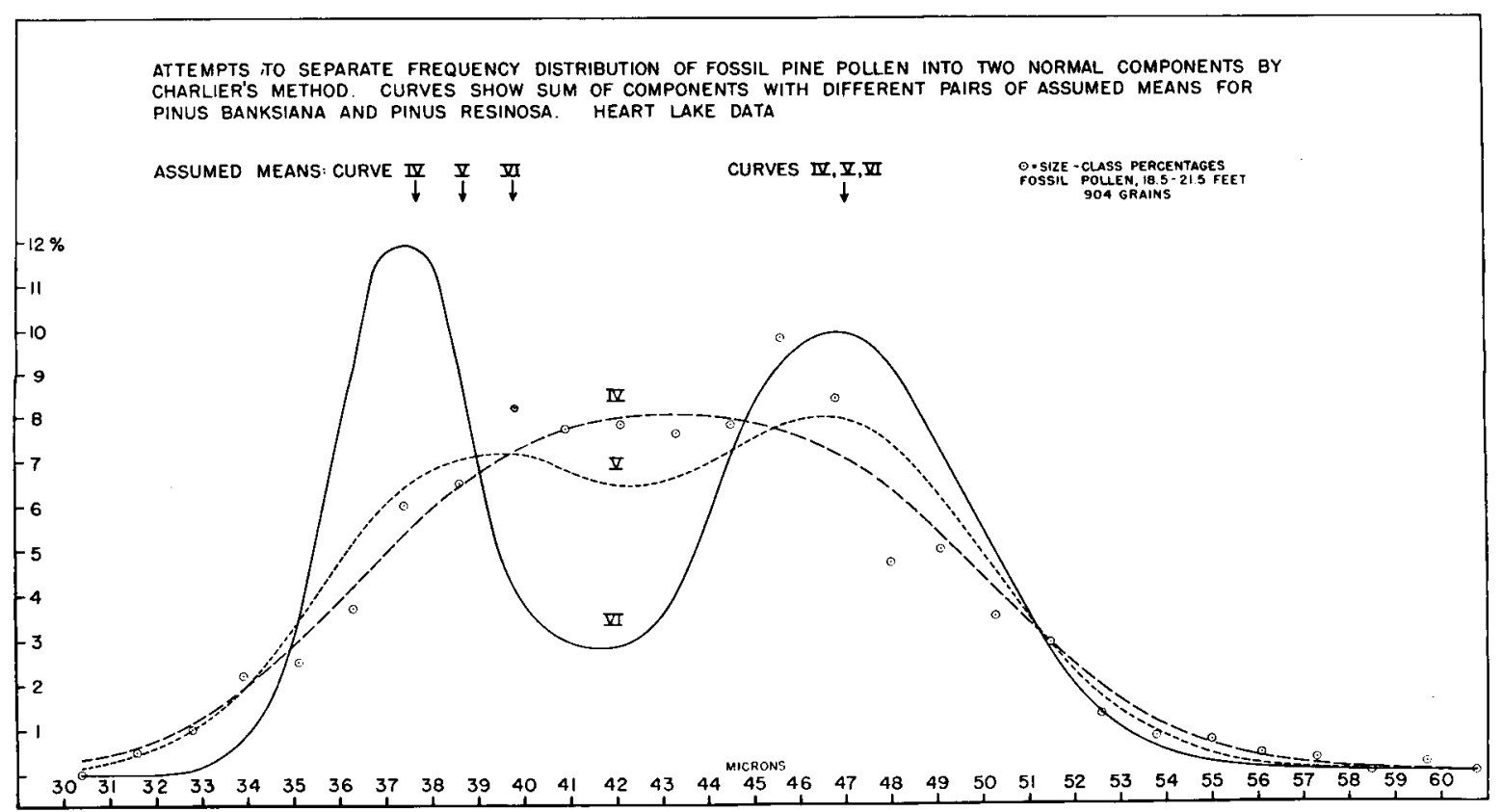

Fig. 6. Further altempts to separate frequency distribution of fossil pine pollen into two normal components by Charlier's method.

deviation and third moment of the data. Various pairs of assumed means of the component distributions are tried until the sum of components agrees with the observed distribution. Although the method is very sensitive, yielding various unimodal and bimodal curves for mixed populations, no fit to the data for fossil grains was obtained. The failure to obtain a solution may have been caused by skewed rather than normal distributions in the sizefrequency characteristics of the pollen of the species contributing to the fossil pollen.

\footnotetext{
Department of Conservation,

University OF Michigan,

Ann Arbor, Michigan
} 


\section{LITERATURE CITED}

Bunt, F. W. 1950. Pollen analysis of sediments at Heart Lake, northeastern Oakland Co., Michigan. Thesis. Wayne University. Detroit, Michigan.

Cain, S. A. 1940. The identification of secies in fossil pollen of Pinus by size-frequency determinations. Amer. Jour. Bot. 27: 301-308.

- 1944. Pollen analysis of some buried soils, Spartanburg Co., South Carolina. Bull. Torrey Bot. Club 71 : 11-22.

-. 1948. Palynological studies at Sodon Lake: I. Size-frequency study of fossil spruce pollen. Science 108: 115-117.

-, and Louise G. Cain. 1948. Palynological studies at Sodon Lake: II. Size-frequency studies of pine pollen, fossil and modern. Amer. Jour. Bot. 35: 583591.

$\longrightarrow$ and J. V. Slater. 1948. Palynological studies at Sodon Lake: III. The sequence of pollen spectra, profile I. Ecology 29: 492-500.

Court, A. 1949. Separating frequency distribution into two normal components. Science 110: 500-501.

Leverett, F., and F. B. Taylor. 1915. The Pleistocene of Indiana and Michigan and the history of the Great Lakes. U.S. Geol. Surv. Monogr. 53: 1-529.

Nichols, G. E. 1935 . The hemlock-white pine-northern hardwood region of eactern North America. Ecology 16: $403-422$.

\section{A NEW LEPIDODENDRON FROM ILLINOIS ${ }^{1}$}

\section{Robert A. Evers ${ }^{2}$}

THE COAL BALL which furnished the material for this study was one of twelve collected by J. W. Hall and the author at the New Delta Mine near Absher, Williamson County, Illinois. The coal balls were found scattered in "nests" in the coal seam (No. 6, upper part of the Carbondale Group) and were uncovered during strip mining operations. In order to distinguish the coal ball of this study, it has been labeled HE 2 and is now a part of the collection of the Paleobotany Laboratory of the University of Illinois.

The petrifaction was irregular in shape, somewhat pointed at the extremities. Its over-all length was approximately $15 \mathrm{~cm}$., the greatest width about $10 \mathrm{~cm}$., and the greatest thickness about $7 \mathrm{~cm}$. (fig. 1). Cuts, shown in this figure, were made by a carborundum saw, and peels were taken from all cut surfaces. Of the numerous plant remains found, including many fern sporangia and a poorly preserved Lepidocarpon, one small stem was of most interest and received the greatest amount of study.

This stem was compared with, and found similar to, Protoösmundites wilsonii Andrews and Baxter (1948). Because of this similarity, it was decided to study this stem further; the results and conclusions of the study follow.

1 Received for publication March 28, 1951.

2 This paper is a contribution from the Paleobotany Laboratory, Department of Botany, University of Illinois, Urbana.

It is a pleasure to acknowledge the assistance and guidance given by Dr. W. N. Stewart in the preparation of this article. The writer also wishes to thank others who were of help in this study: Dr. H. N. Andrews of Washington University, for the loan of the type material of Protoösmundites wilsonii, Dr. John $W$. Hall for his assistance in producing the photographic plates, Mr. Robert Kosanke of the Illinois State Geological Survey for directions aiding in the location of the coal balls and for the suggestions which he gave, and Mrs. Elizabeth Derrough Kirk of the Department of Botany, University of Illinois, for the execution of the line drawings.
Numerous peels were made of the stem in both transverse and longitudinal planes. Longitudinal sections were made through the entire stem from one portion of the coal ball, $\mathrm{c}^{2}$ in fig. 1 ; a total of 70 peels was obtained. Slides were made from most of the peels, and these, with few exceptions, are now in the slide collection of the Paleobotany Laboratory of the University of Illinois.

The stem traversed the petrifaction for approximately $8 \mathrm{~cm}$. In the upper portion of $c^{0}$ and $c^{1}$ it was quite straight but in the lower portions of $c^{2}$ it was bent strongly, becoming somewhat flexuous in $\mathrm{d}$ and was then lost. In addition to this stem, a similar but smaller one was found in close proximity in the upper portion of the coal ball, $c^{0}$. Whether this is a branch of the larger stem was not determined as the smaller one is not found in the next lower piece, $\mathrm{c}^{1}$, and any branching would have had to occur through a distance of $2 \mathrm{~mm}$. (the width of the saw cut), which seems unlikely.

Structure of THE STEM.-The peels, when placed under low-power magnification, show the stem to be composed of a siphonostele surrounded by a cortex and numerous attached leaf-cushions (fig. 9). Although the stele is cylindrical, the cortical tissues are much compressed. The cross-section of the entire stem measures $3 \times 15 \mathrm{~mm}$. in its minimum and maximum diameters; the stele itself is $1.16 \mathrm{~mm}$. in diameter (fig. 13).

The primary xylem is exarch, and the stele contains no secondary xylem. In cross-section, the metaxylem elements are largest adjacent to the pith and diminish in diameter toward the periphery of the stele, merging with smaller cells which are groups of protoxylem elements. Numerous leaftraces pass off from these protoxylem groups.

The pith, occupying the center of the stele, measures $0.4-0.5 \mathrm{~mm}$. in diameter. Its cells vary from $30-50 \mu$ in diameter and are approximately $180-300$ 